\title{
Joseph K. Claims Compensation: Franz Kafka’s Legal Writings
}

\author{
Robert M. Kaplan \\ Graduate School of Medicine, University of Wollongong, New South Wales, Australia \\ Email: rob@rmkaplan.com.au
}

Received 28 October 2013; revised 7 December 2013; accepted 18 December 2013

Copyright (C) 2014 by author and Scientific Research Publishing Inc.

This work is licensed under the Creative Commons Attribution International License (CC BY).

http://creativecommons.org/licenses/by/4.0/

\section{(c) (i) Open Access}

\begin{abstract}
Franz Kafka worked for 22 years for an insurance company, writing reports and preparing cases. His legal writings provide an insight into how his work experiences were a source and inspiration for his literary endeavours. Kafka described the alienation and exclusion of the individual in the face of modern bureaucracy. In works such as The Trial and The Castle, the individual is confronted with a baffling series of claims, obstacles and threats; as soon as one hurdle is overcome, another appears. The term "Kafkaesque" has become part of the English vernacular. Kafka's legal work provides an insight into the problems faced by workers making legal claims, notably the alienation and frustration produced by the process. Today there is a growing recognition in the legal system of the importance of Kafka's work and his writing, notably The Trial, which is being incorporated into the burgeoning study of law and literature.
\end{abstract}

\section{Keywords}

Kafka; Medico-Legal; Forensic; Literature; Workplace Injury; Insurance

\section{Introduction}

"It is certainly an excellent arrangement", the official says, "always unimaginably excellent, even if in other respects hopeless".

Franz Kafka, “The Castle” (Wood, 2008).

Franz Kafka, one of the great German-language writers of the twentieth century, described the alienation and exclusion of the individual in the face of modern bureaucracy. The term "Kafkaesque" has become part of the English vernacular. W. H. Auden said that Kafka was to the twentieth century what Dante, Shakespeare, and Goethe were to their respective centuries (Auden, 1962). In works like The Trial and The Castle, the individual 
is confronted with a baffling series of claims, obstacles and threats; as soon as one hurdle is overcome, another appears (Rowe, 2002); Joseph K. in The Trial never finds out who his accusers are; in Metamorphosis, GregoSamsa wakes to find that he has been transformed into a giant, repulsive insect who is rejected by his family (Kafka, 1961).

\section{Kafka's Legal Career}

But Kafka had a day job. Unable to have any means of supporting himself as a writer, he studied law by default after he failed to find anything compatible with his "self-absorption and vanity". His response to his legal studies was characteristic: "For the few months before the final university exam, my mind was fed with intellectual sawdust which had been chewed by a thousand mouths before".

Obtaining the degree of Doctor of Law from Ferdinand-Karls University in Prague on 18 June 1906, he then did the obligatory year of unpaid service as law clerk for the civil and criminal courts. Working for the Assicurazioni Generali for two years, he took classes at the Handelsakademie [Trade Academy] on worker's compensation insurance, receiving excellent grades.

On 30 July 1908, Kafka was employed at the Arbeiter-Unfall-Versicherungs-Anstaltfür das Königreich Böhmen (the Worker's Accident Insurance Institute for the Kingdom of Bohemia) in Prague, one of only two Jews in the company. The Workmen's Accident Insurance Law of 1889 in the Austro-Hungarian Dual Monarchy followed Bismarck's German social welfare reforms. The legislation aimed at regulating relations between capital and labour, as well as the relationship between the State and the worker (Pawell, 1997). In highly industrialized Bohemia, the Prague Institute had an important role. It was responsible for determining and collecting insurance premiums covering work-related injuries for all types of industrial settings.

The insurance premiums employers had to pay were based on the firm's risk classification. The greater the risk of accidents, the higher the premium paid; the smaller the risk, the lower the premium. While the intention was to correct the unjust treatment of workers, the law often resulted in corruption and inefficiency. Because of lax enforcement of the rules, employers would often aim for the lowest risk classification, which led to influence peddling, fraudulence, overcharging of the other employers and a huge financial deficit for the Institute.

Despite the resistance to promoting Jews, Kafka progressed through the positions of deputy clerk and trainee, getting the permanent rank of law clerk (Concipist) in April 1910. He subsequently became Vice-Secretary, a position he held until 1922, when he became too unwell to work, dying in 1924. Besides being involved in litigation, Kafka produced official declarations, commentaries, petitions, reports, briefs to speeches and newspaper articles. He promoted universal coverage, seeking to extend compulsory accident insurance and make sure that equal treatment was extended to all members of the work force.

\section{The Interface between Kafka's Legal and Literary Work}

Kafka's legal work was held in high esteem and in 1913, he accompanied Robert Marschner and Eugen Pfohl, the two leading officials at the Institute, to the Second International Congress on Accident Prevention and First Aid held in Vienna. The speeches they delivered (written by Kafka) were later to recur as fragments in Building the Great Wall of China. The meeting was not just a career highlight for him, but gave him the opportunity to attend the Eleventh Zionist Congress, which had a significant influence on his views on Judaism (Cohen, 1997).

Kafka served as Appeals Officer for risk classification and went to great lengths to apply himself to the problem of injury prevention, frequently stating that the best outcome for all the parties was to ensure the accident did not happen in the first place (Singer, 2006). He was profoundly moved, shaken and appalled by the plight of the injured worker in the face of employer resistance (if not hostility), bureaucratic ineptitude and public indifference.

He wrote to Max Brod, his friend and executor:

"In my four districts—apart from all my other jobs_-people fall off the scaffolds as if they were drunk, or fall into the machines, all the beams topple, all embankments give way, all ladders slide, whatever people carry up falls down, whatever they hand down they stumble over. And I have a headache from all these girls in porcelain factories who incessantly throw themselves down the stairs with mounds of dishware" (Kafka, 1997).

Kafka constantly complained that work interfered with his writing - but then he complained about just about everything in his life (Densky, 2010). In fact, Kafka’s professional work was highly regarded, he took pride in what he did and distributed his articles to friends.

While Kafka published fewer than 450 pages in his lifetime, a new book on his work has been published 
every 10 days for the past 14 years (Batuman, 2010). While there is an enormous Kafka industry, his legal writing was largely unknown until a search of the Institute archives retrieved many of his documents-even his job application-and the collection was published in German (Hermsdorf \& Wagner 2004). This was culled to eighteen of the most relevant pieces in the English translation (Corngold et al., 2009). The chapters, consisting of legal documents, petitions, commentaries and newspaper articles, are written in a formal and appropriate style showing the confluence of civil law and administrative bureaucracy (Murray, 2004). The collection reveals the extent to which Kafka's experience in law influenced his writing (Preece, 2002). Eight of his works relate directly to the law: The Trial, Before the Law, The Problem of Our Laws, In the Penal Colony, The Refusal, The New Advocate, The Knock at the Manor Gate and The Stoker.

Kafka's concise and unpretentious literary prose has much in common with the reports he wrote for his work. The Castle, for example, is written in a sober, detailed and at times legalistic style. At the same time, a characteristic sense of unreality prevails. A good example of Kafka's writing is seen in an excerpt from his report on “Accident Prevention Regulations on the Use of Wood-Planing Machines” (Corngold, 2008):

Not only every precaution but also all protecting devices seem to fail in the face of this danger, as they either proved to be totally inadequate or, whereas they reduced the danger on the one hand (automatic covering of the cutter slot by a protecting slide, or by reducing the width of the cutter space), they increased it on the other by not allowing the chippings sufficient space to leave the machine, which resulted in choked cutter spaces and in injured fingers when the operator attempted to clear the slot of chippings.

The similarity with his fictional writing can be seen in the description of the execution machine from "In the Penal Colony”:

It was a huge affair. The Bed and Designer were of the same size and looked like two dark wooden chests. The Designer hung about two meters above the Bed; each of them was bound at the corners with four rods of brass that almost flashed out rays in the sunlight (Corngold et al., 2009).

In turn, Kafka's reports draw on his fictional writing, for example in his public appeal for funding of a psychiatric hospital for World War 1 veterans:

Soon after the outbreak of war, a strange apparition, arousing fear and pity, appeared in the streets of our cities. He was a soldier returned from the front. He could move only on crutches or had to be pushed along in a wheelchair. His body shook without cease, as if he were overcome by a mighty chill, or he was standing stock-still in the middle of the tranquil street, in the thrall of his experiences at the front we see others, too, men who could move ahead only by taking jerky steps; poor, pale, and gaunt, they leaped as though a merciless hand held them by the neck, tossing them back and forth in their tortured movements (Corngold et al., 2009).

This article shows Kafka's conceptualisation of military mental disorder, not as a distinct condition, but on a continuum from the industrial disorders of civilian life.

Just as the intensive operation of machinery during the last few decades peacetime jeopardised, far more than ever before, the nervous systems of those so employed, giving rise to nervous disturbances and disorders, the enormous increase in the mechanical aspect of contemporary warfare has caused the most serious risks and suffering for the nerves of our fighting men (Corngold et al., 2009).

This is an important issue in medico-legal jurisprudence today.

Kafka displayed considerable technical skill in designing devices to prevent injuries; for example, a cylindrical wood-planing machine, with enhanced protection requiring quarry workers to wear eye-protecting goggles. These machines resemble the torture machine of the Penal Colony where a man condemned to death for falling asleep on duty is to be executed by “the remarkable piece of apparatus”.

Kafka was not an officer of the court, but an insurance lawyer working at a quasi-official Institute. In this capacity, he was simultaneously an insider and an outsider to legal processes and institutions (Lutowitz, 2002). The legal writings show how Kafka combined internal and external views of the law (Banakar, 2010). The Institute with its hierarchy of officials, clerks and lawyers, had its own bureaucracy, typical of all such institutions, leading to a maze of difficulties for any claimant and typifying the confluence of civil law and administrative bureaucracy (Arendt, 1981).

While Kafka's professional and literary activities were kept separate, a number of situations he encountered at work would later appear among the characters, settings, and images in his fiction; for example, a 1914 report on safety described “a loose stone block" in a quarry (Corngold et al., 2009). That year Kafka began writing The Trial, which ends in a execution scene in a quarry.

Another example can be given: Kafka had extensive involvement in the case of Josef Franz Renelt, the owner 
of an orchard and a quarry in the village of Aussig (Corngold et al., 2009). The Institute claimed Renelt had defrauded them for ten years by listing some of his quarry workers, whom he was required by law to insure, as orchard workers who were exempt from the insurance requirement. The Institute, in return, breached the rules of insurance law, by interviewing Renelt's employees without his knowledge. The Institute pursued Renelt for nine years in an attempt to make an example of him. Evidence was difficult to gather, witnesses recanted, memories failed, and Renelt's side used physical force to get records from investigators. Kafka participated in the litigation. The case proceeded to the insurance tribunal and criminal and administrative courts before Renelt finally won on a technical point.

The Renelt case recurs in three of Kafka's major novels. In The Man Who Disappeared (Kafka, 1961), written at the time the case began, Karl Rossmann loses his job and encounters a policeman. After a short interrogation, he attempts escape and runs away again. Shortly afterwards, Kafka started writing The Trial, a novel about a man in trouble with the law. Just as Renelt had faced both insurance law and criminal law, Joseph K.-who, like Renelt was not in custody - tries to identify the jurisdiction he is dealing with. In a deleted passage of The Castle, there is a comment on the struggle for physical possession of written evidence as had occurred in Renelt's matter.

\section{Discussion}

"The right perception of any matter and a misunderstanding of the same matter do not wholly exclude each other".

The Trial.

The Trial is not just a work of literature, but a powerful warning of the dangers of arbitrary government (Kershaw, 2009). Joseph K. awakes one morning to find himself accused by a mysterious legal authority: "Someone must have been spreading lies about Joseph K., for without having done anything wrong he was arrested one fine morning" (Kafka, 1999). His alleged crime is unnamed, something of which he knows nothing. K's "trial" is the hellish ordeal of being an accused person living with the threat of conviction, imprisonment or worse for no stated reason (Kershaw, 2008). The novel follows his many attempts to obtain justice from authorities with which he cannot communicate. This however ends in utter frustration with his loss of dignity and his brutal death by stabbing when he dies "like a dog" (Zizek, 1995). Kafka was able to create a compelling and terrifying world in which the government could, seemingly at random, single its citizens out for punishment in the name of the law. This is even more remarkable because Kafka, unlike Orwell, for example, was not political and did not intend for his stories to be parables (Blackmore, 2009).

What makes The Trial all the more influential is that it is not set in any single nation or any particular period of time. Its main character is honest, hardworking, and nondescript; the reader finds him easy to relate to. The story's theme transcends cultures and time. The trial of Joseph K. is as relevant today as it was in Kafka's time.

Kafka's work offers insights into aspects of the complex relationship between modern law, justice, and bureaucracy. Around the world, the ragged interface between the state, labour and capital is policed by different systems. The result, for any party involved in this scenario, is unsatisfactory (Marx, 1976). Employers regard insurance premiums as punitive and consider many (if not all) claimants to be malingering. Insurance companies perceive themselves as negotiating between two intractable parties. Once they enter the system, the hapless worker becomes a passive and powerless entity, passing as if on a conveyor belt to a series of doctors, lawyers and assessors, the voyage characterised by a sense of helplessness, alienation and despair. It is a process that can only be characterised as... Kafkaesque.

These issues played out in many aspects of Kafka's writing, leaving no doubt that Kafka the lawyer was Kafka the writer. Kafka's legal writings reveal that it was not possible to have the one and not the other; the triangular situation of worker, employer and insurance company was a chess board on which played out mostly set-piece moves that often defined the clash between capital and labour, the individual and society.

Kafka sought to apply the existing laws not only with fairness, but with compassion. His legal opinions are a careful search for the meaning or intentionality of texts. His briefs are brilliant examples of the convergence of juridical and linguistic thinking. In The Scope of Compulsory Insurance for The Building Trades (Pawell, 1997), Kafka recognizes the tension between a "top-down" bureaucracy based on centralized power and a "bottom-up" model based on the voices of the individuals. 


\section{Kafka's Legacy}

Kafka holds a special fascination for legal scholars because he was a practicing lawyer who often wrote about the law and legal systems with harrowing portraits of legal outsiders. He did not write from the perspective of a legal insider, such as a judge, lawyer or prosecutor, but depicted the position of outsiders subjected to an unknowable and alienating legal system composed of layers of petty officials.

Joseph K., the protagonist of The Trial, is subjected to criminal proceedings according to the Austro-Hungarian law of the time, whereas the Land Surveyor $\mathrm{K}$ in The Castle is engaged in what amounts to a civil law dispute with the Castle authorities who have allegedly summoned him. Kafka's dominant theme in these and other works is that the search for the law involves a series of endless delays. The best example of this is can be found in his story Before the Law (Kafka, 1961) where an old man from the country dies while waiting for permission from a legal gatekeeper to enter the law. Joseph K. in The Trial never appears before a judge and K in The Castle never gets the desired audience with the authorities in the castle who run the village. In contrast to modern legal fiction, Kafka's writing never provides a crusading protagonist who will strike down the law to provide a just solution.

Joseph K., the protagonist of The Trial, is subjected to criminal proceedings according to the Austro-Hungarian law of the time, whereas the Land Surveyor K. in The Castle is engaged in what amounts to a civil law dispute with the Castle authorities who have allegedly summoned him.

Kafka's view of law was shaped by the civil tradition in which he worked. He studied canon law and Roman law, which is not usually taught in common law countries. His descriptions of the legal proceedings in The Trial - undoubtedly the index description of a "Kafkaesque” situation-are based on the inquisitorial system of German and Austrian criminal proceedings, not Anglo-Saxon adversarial justice (Lutowitz, 2002). Nevertheless, his popularity in the English-speaking world is an indication that his work is just as relevant to common law (Hawes, 2008). Viewed through the lens of outsider jurisprudence, Kafka's work is an extended mediation on the position and perspective of the legal outsider. Most of his works, including The Trial and The Castle are about those who seek the law, but never find it, endlessly frustrated by a series of petty bureaucrats. The prevalent theme is that the search for the law involves a series of endless delays.

Kafka's vision of a threatening and pointless bureaucracy was first encapsulated in the English word “Kafkaesque”, in 1946. Webster defines “Kafkaesque” as meaning “of, relating to, or suggestive of Franz Kafka or his writings; especially: having a nightmarishly complex, bizarre, or illogical quality” (Merriam-Webster Online Dictionary, 2008). Jeremy Adler states that the adjective "Kafkaesque” "denotes nightmarish situations, an all-pervasive bureaucracy, looming totalitarianism, infinite hierarchies, and a deep existential angst” (Adler, 1985). Courts often use "Kafkaesque" to characterize an argument as illogical, or one that would lead to an absurd result (Blackmore, 2009).

The term Kafkaesque has been used in a number of legal situations. These situations include cases where there is: deprivation of due process; police or government abuse of an individual's civil rights; violation of the rules of court; victimization of individuals by government; situations violation of the discovery rule; withholding evidence against a person so that they are unable to present their case adequately; the absence or inadequacy of an interpreter at a trial; and the appearance of arbitrariness on the part of the court. The term has also been used to indicate excessive government intrusion into the individual's right to privacy (Finet, 1988). Amidst the welter of uses of Kafkaesque in different courts and different jurisdictions, three Australian examples have arisen in relation to: post 9/11 control orders (Bachmann, Oliver, \& Burt, 2010), workers’ compensation dispute resolution in Western Australia (Guthrie, Goldacre, \& Claydon, 2008) and Indigenous legal issues after the discrediting of the Terra Nullius concept (Howard, 1998).

Kafka's fictional and legal writing expresses the paradox that lies at the heart of the relationship between law, which strives toward generality and universality, and justice, requiring the recognition of singularity and specificity. He was familiar with Gross's idea that "it is not the crime but the criminal who is the proper object of punishment” (Ziolkowski, 2003). This idea determined the fate of Joseph K., who is subjected to an incomprehensible form of injustice. The people Kafka depicts are not members of minorities, but "situational outsiders" for various reasons, who never achieve a satisfactory outcome, but remain suspended or condemned. His concern was to find the intention, that is, the meaning, of the law. In The Trial and The Castle, Kafka's protagonists are neither innocent nor victims of a bureaucratic system. They appear as victims only because Kafka is telling the story from their point of view and not from the standpoint of the court or the Castle, which, being bureau- 
cratic systems, cannot have a personal point of view.

Kafka is increasingly the subject of legal scholarship (West, 1986) and his work has been cited in articles dealing with family law, globalization, internationalism, critical legal studies, jurisprudence, immigration and employment (Weisbrod, 1993; Westbrook, 2003;Grazin, 1999; Morgan, 1999; Litowitz, 2002; Dragich, 1998; Akram, 1999; Hermsdorf \& Wagner 2004; Kraus, 1999). Kafka references are becoming more common in judicial opinions - to such an extent that one author considered it to at risk of becoming a debased coinage (Pinaire, 2007). The name "Franz Kafka” appears in 54 US federal and state court opinions. "Kafkaesque” has been used in 363 federal and state court opinions. "The Trial” is listed in 207 cases in the same paragraph as "Kafka” (Blackmore, 2009). Judges use K. Joseph's nightmare to make the point that government transparency and fairness are fundamental in our society (Lukács, 2000).

Kafka, along with writers like Herman Melville and Charles Dickens, is central to the development of the burgeoning study of law and literature (Posner, 1986). United States Supreme Court Justice Anthony Kennedy recommended that all lawyers - better than that, all law students_-should read The Trial (Carter, 1993):

"The Trial is actually closer to reality than fantasy as far as the client's perception of the system. It's supposed to be fantastic allegory, but it's reality. It's very important that lawyers read it and understand this".

Kafka was able to create a compelling and terrifying world in which the government could, seemingly at random, single its citizens out for punishment in the name of the law.

A century ago, the Jewish Jackdaw (Kafka means jackdaw in Czech) of Prague spent his days seeing claimants, writing reports and arguing with employers. Then he went home at night to write the works that better than any other reveal the state of the modern individual dealing with the bureaucracies of the time. Kafka's writing has as much relevance for contemporary law as they did in Bohemia a century ago. Any law, civil or criminal, has the capacity to strip the individual of his dignity, leaving him alienated, dispirited and defiled. We need Kafka now as never before.

To write prescriptions is easy, but to come to an understanding with people is hard.

Franz Kafka, “A Country Doctor”.

\section{Acknowledgements}

Thanks to Lisa Paraska and Rachael Zavodniuk for comments and encouragement.

In his day job, the author spends his time preparing medico-legal reports, a process that, in the current climate, could drive anyone to spending their nights reading Kafka.

\section{References}

Adler, J. (1995). Stepping into Kafka’s Head, Times Literary Supplement. http://www.textkritik.de/rezensionen/kafka/einl_04.htm

Akram, SM. (1999). Scheherezade Meets Kafka: Two Dozen Sordid Tales of Ideological Exclusion. Georgetown Immigration Law Journal, 14, 28.

Arendt, H. (1981). Franz Kafka, in Franz Kafka: An Anthology of Marxist Criticism. Univ. Press of New England.

Auden, W. H. (1962). The Dyer's Hand, and Other Essays. New York: Random House.

Bachmann, S. D., Oliver, V., \& Burt, M. (2011). Control Orders Post 9-11 and Human Rights in the United Kingdom, Australia and Canada: A Kafkaesque Dilemma? Deakin Law Review, 15, 131.

Banakar, R. (2010). In Search of Heimat: A Note on Franz Kafka's Concept of Law. Law and Literature, 22, 463-490.

Batuman, E. (2010). Kafka’s Last Trial. New York Times.

http://www.nytimes.com/2010/09/26/magazine/26kafka-t.html?pagewanted=all

Blackmore, J. (2009). The Influence of Franz Kafka on American Jurisprudence.

http://works.bepress.com/jonathan_blackmore/1

Carter, T. (1993). A Justice Who Makes Time to Read, and Thinks All Lawyers Should, Too. Chicago Daily Law Bull.

Cohen, G. B. (1977). Jews in German Society: Prague 1860-1914. Central European History, 10, 28-54.

Corngold, S., et al. (Eds.) (2009). Franz Kafka: The Office Writings. Princeton: Princeton University Press.

Densky, D. (2010). Franz Kafka: The Office Writings (Review). Modernism/Modernity, 17, 957-959.

Dragich, M. J. (1998). Justice Blackmun, Franz Kafka, and Capital Punishment. Missouri Law Review, 63, 853. 
Finet, S. (1988). Franz Kafka’s Trial as Symbol in Judicial Opinions. Legal Studies Forum, 12, 23-35.

Grazin, I. (1999). Kafka's Myth of Law in the Context of the Legal Irrationality Inspired by the Russian Post-Communist Market. Michigan State University-DCL Journal of International Law, 8, 335-65.

Guthrie, R., Goldacre, L., \& Claydon, W. (2008). Workers’ Compensation Dispute Resolution Procedures in Western Australia-The New Regime: [Paper in Special Edition: Alternative Dispute Resolution]. Law and Justice Journal, 8, 46-76.

Hawes, J. (2008). Why You Should Read Kafka Before You Waste Your Life (pp. 212-214). New York: St. Martin’s Press.

Hermsdorf, K., \& Wagner, B. (Eds.) (2004). Franz Kafka: AmtlicheSchriften. Frankfurt am Main: S. Fischer Verlag.

Howard, J. D. (1998). Indigenous Legal Issues. In the Wake of Terra Nullius. Political and Legal Anthropology Review, 21, 132-134.

Kafka, F. (1961). Metamorphosis and Other Stories, trans. Will and Edwin Muir. Mitcham: Penguin.

Kafka, F. (1977). Letters to Family, Friends, and Editors. New York: Schocken Books, 58.

Kafka, F. (1995). The Complete Stories. In N. N. Glatzer (Ed.), New York: Schocken Books, 220.

Kafka, F. (1999). The Trial. New York: Schocken Books.

Kafka, F. (2004). Franz Kafka: Amtliche Schriften. In K. Hermsdorf, \& B. Wagner (Eds.), Frankfurt am Main: S. Fischer Verlag.

Merriam-Webster Online Dictionary (2008). Kafkaesque. Merriam-Webster Online. http://www.merriam-webster.com/dictionary/Kafkaesque

Kershaw, R. B. (2009). Kafka’s the Trial: An Enigma Encountered. The Journal Jurisprudence, 1, 307.

Kraus, A. W. (1999). Assessing Mr. Samsa’s Employee Rights: Kafka and the Art of the Human Resource Nightmare. American Bar Association, The Labor Lawyer, 15, 309-319.

Litowitz, D. E. (2002). Franz Kafka’s Outsider Jurisprudence. Law \& Social Inquiry, 27, 103-137. http://dx.doi.org/10.1111/j.1747-4469.2002.tb01109.x

Lukács, G. (2000). History and Class Consciousness: Studies in Marxist Dialectics. Cambridge, MA: The MIT Press, 224.

Marx, K. (1976). Capital: A Critique of Political Economy. Volume I. Book One: The Process of Production of Capital. https://www.marxists.org/archive/marx/works/1867-c1/

Morgan, E. (1999). In the Penal Colony: Internationalism and the Canadian Constitution. University of Toronto Law Journal, 49, 447-474.

Murray, N. (2004). Kafka: A Biography. New Haven, CT: Yale University Press, 38.

Pawell, E. (1997). The Nightmare of Reason: A Life of Franz Kafka. New York: Farrar, Straus and Giroux, 183.

Pinaire, B. (2007). The Essential Kafka: Definition, Distention, and Dilution in Legal Rhetoric. University of Louisville Law Review, 113, 151.

Posner, R. A. (1986). Law and Literature: A Relation Reargued. Cambridge, MA: Harvard University Press.

Preece, J. (2002). The Cambridge Companion to Kafka. Cambridge: Cambridge University Press, 131-132.

Rowe, M. (2002). Metamorphosis: Defending the Human. Literature and Medicine, 21, 264-280.

Singer, S. (2006). Franz Kafka-Serious about Your Safety. Salmagundi, 150/151, 311.

Zizek, S. (1995). Ideology between Fiction and Fantasy. Cardozo Law Review, 1511, 1511.

Ziolkowski, T. (2003). Mirror of Justice: Literary Reflections of Legal Crisis. Princeton, NJ: Princeton University Press, 225.

West, R. (1986). Submission, Choice, and Ethics: A Rejoinder to Judge Posner. Harvard Law Review, 99, 1449.

Weisbrod, C. (1993). Family Governance: A Reading of Kafka’s Letter to His Father. University of Toledo Law Review, 689, 686.

Westbrook, D. A. (2003). Triptych: Three Meditations on How Law Rules After Globalization. Minnesota Journal of Global Trade, 12, 337.

Wood, M. (2008). Double Thought. London Review of Books, 30, 3-5. 